\title{
Hubungan Antara Kepribadian Introvert Dan Ekstrovert Dengan Speaking Skill Mahasiswa Prodi D III Keperawatan Tahun
} Akademik 2017/2018

\author{
Siswoto Hadi Prayitno \\ Akademi Kesehatan Rustida \\ siswotohp@gmail.com \\ Sylene Meilita Ayu \\ Akademi Kesehatan Rustida \\ sylenemeilitaayu@yahoo.co.id
}

\begin{abstract}
Abstrak
Tipe kepribadian introvert memiliki ciri ketika menghadapi sesuatu banyak dipengaruhi oleh faktor subyektif yang berasal dari dunia batin, sebaliknya kepribadian ekstrovert memiliki ciri lebih terbuka dan lebih dapat bersosialisasi. Perbedaan kedua kepribadian tersebut berpengaruh pada kemampuan berkomunikasi dan bersosialisasi, termasuk kecakapan berkomunikasi Bahasa Inggris. Penelitian ini bertujuan mengetahui hubungan tipe kepribadian introvert dan ekstrovert dengan speaking skill mahasiswa semester 1 Prodi D III Keperawatan Rustida Tahun Akademik 2017/2018. Jenis penelitian ini adalah deskriptif kuantitatif non eksperimental. Populasi penelitian ini mahasiswa semester 1 Prodi D III Keperawatan Rustida dengan sampel sebanyak 38 mahasiswa. Teknik analisis data kolmogrov smirnov test digunakan untuk mengetahui hubungan antar variabel. Hasil penelitian menunjukkan nilai $p 0.807$ $>0.05$ yang artinya tidak ada perbedaan secara bermakna antara tipe kepribadian ekstrovert dan introvert terhadap speaking skill mahasiswa. Motivasi belajar, dan peran dosen dalam pembelajaran, juga merupakan faktor yang mempengaruhi speaking skill.
\end{abstract}

Kata kunci: tipe kepribadian introvert; ekstrovet; speaking skill.

\section{Pendahuluan}

Keterampilan berbicara (speaking skill) dalam Bahasa Inggris merupakan suatu keterampilan seseorang untuk menyampaikan hasrat dan pemikirannya kepada siapa saja melalui lisan, akan tetapi, keterampilan berbicara sulit berkembang kalau tidak dilatih secara terus menerus dan bisa dilakukan dengan rekan-rekan di dalam kelas, guru maupun dosen Bahasa Inggris, atau guru 
maupun dosen lainnya yang bisa berbahasa Inggris. Tujuannya untuk memperlancar keterampilan berbicara, memperkaya penggunaan kosa kata, memperbaiki tatanan berbahasa, menyempurnakan ucapan-ucapan kosa kata, kalimat-kalimat Bahasa Inggris, dan melatih pendengaran sehingga mudah menangkap pesan dari lawan bicara.

Kemampuan berbicara dalam Bahasa Inggris yang masih rendah dapat terjadi pada sebagian mahasiswa. Kadang mahasiswa mengalami kesulitan ketika berkomunikasi dalam Bahasa Inggris, hal ini terlihat dari cara mengekspresikan baik secara lisan yang masih mengalami kesulitan, penggunaan kosa kata, kurang berani memulai berbicara dalam Bahasa Inggris baik kepada pengajar mapun kepada teman teman di kelas (Agus Suganda, Arif Hidayat, Indri Widayastuti, 2010). Pengaruh globalisasi di berbagai bidang kehidupan menuntut adanya inovasi dan peningkatan kualitas sumberdaya manusia terutama kemamampuan berkomunikasi dalam Bahasa Inggris agar mampu bersaing di dunia kerja terutama di level international (Ratih, 2005). Pembelajaran dengan menggunakan Bahasa Inggris sudah dimulai dari tingkat Sekolah Dasar sampai ke tingkat perguruan tinggi, namun kenyataanya hanya sebagaian kecil mahasiswa yang terampil dalam berkomunikasi, kemungkinan penyababnya adalah pembelajaran kurang menarik, situasi terlalu tegang dan kurang pembiasaan dengan berkomunikasi dalam Bahasa Inggris sehari-hari (Sutiyoso, 2010).

Mahasiswa yang memiliki kepribadian introvert biasanya mengalami kesulitan dalam berkomunikasi verbal yaitu mengalami kesulitan dalam mengungkapkan apa yang di dalam isi hatinya dan ini berbeda dengan kepribadian ekstrovert (Zubaidah, 2017).

Kemungkinan penyebab kurang terampilnya berbahasa Inggris oleh karena peserta didik memiliki kepribadian yang introvert dimana individu dengan kepribadian ini memiliki sifat malu dan hanya mau menjadi pendengar sehingga kurang dapat melatih, tentu berbeda dengan kepribadian type ekstrovert (Butsi, 2016). Pelajar yang memiliki kepribadian tertentu dapat berpengaruh pada kemamampuan dalam komunikasi (Ayu, Wiryadi, Ayu, \& Dharmayanti, 2016), terutama dalam belajar komunikasi Bahasa Inggris harus sering dibiasakan dalam 
kehidupan sehari-hari serta tidak memiliki sifat ragu dalam berlatih (Agus Suganda, Arif Hidayat, Indri Widayastuti, 2010). Dalam penelitian terdahulu ditemukan bahwa pelajar yang memiliki kepribadian introvert memiliki nilai berbicara yang lebih baik dari pada yang memiliki kepribadian ekstrovert (Samandi, 2014).

Berkomunikasi dengan menggunakan Bahasa Inggris dapat dilihat dari kemampuan individu dalam menjawab pertanyaan pada pokok bahasan saja dan kurang dapat mengembangkan jawaban, hal ini menggambarkan kemampuan berbicara dalam Bahasa Inggris yang masih kurang (Agus Suganda, Arif Hidayat, Indri Widayastuti, 2010). Kemungkinan kemampuan dalam berkomunikasi menggunakan Bahasa Inggris masih rendah dikarenakan frekuensi pembelajaran diperguruan tinggi kurang mendukung, diberikan dalam SKS yang sedikit dan frekuensi pertemuan hanya seminggu satu kali (Hermayawati, 2010). Meskipun faktor tipe kepribadian dapat mempengaruhi dalam berkomunikasi dengan Bahasa Inggris (Samandi, 2014), namun peningkatan kualitas pembelajaran perlu diperbaiki, karena penguasaan Bahasa Inggris dapat membuka wawasan termasuk perkembangan ilmu dan terhnologi demikian juga dengan akses belajar yang lebih mudah dari berbagai sumber (Hermayawati, 2010).

Kepribadian introvert memiliki ciri dimana dalam menghadapi sesuatu banyak dipengaruhi oleh faktor subyektif yang berasal dari dunia batin sendiri, sebaliknya kepribadian ekstrovert memiliki ciri lebih terbuka dan lebih dapat bersosialisasi (Azizah, 2016). Perbedaan kedua kepribadian tersebut berpengaruh pula dengan kemampun berkomunikasi dan bersosialisasi (Zubaidah, 2017), terutama kecakapan komunikasi dengan Bahasa Inggris (Samandi, 2014). Metode pengembangan pembelajarn harus dilakukan guna meningkatkan kemamapuan dan ketrampila mahaiswa dalam berkomunikasi (Zubaidah, 2017) terutama dengan menggunakan Bahasa Inggris (Samandi, 2014).

Ditinjau dari latar belakang penelitian, maka peneliti melakukan kajian mendalam untuk mengetahui adakah hubungan antara kepribadian introvert dan ekstrovert dengan speaking skill mahasiswa semester 1 Prodi D III Keperawatan Rustida Tahun Akademik 2017/2018. 


\section{Tinjauan Pustaka}

Kepribadian merupakan suatu kesatuan dari individu yang unik (Kuntjojo, 2009) dan merupakan sifat hakiki dari individu yang tercermin pada sikap dan perbuatannya yang membedakan dirinya dengan yang lain (Winarso, 2015), termasuk upaya yang dilakukan individu dalam menyesuaian diri yang memiliki keanekaragaman yang khas (Catrunada, 2014).

Tipe kepribadian merupakan suatu klasifikasi mengenai individu dalam satu atau dua ataupun lebih kategori, atas dasar dekatnya pola sifatnya yang cocok dengan kategori tipe tadi (Aliyah, 2006). Tipe kepribadian diakui merupakan sesuatu yang dasar dan penting dalam mempelajari karakter manusia dengan segala tingkah lakunya, dengan mendalami dan memahami karakter manusia berdasarkan tipe kepribadiannya, maka akan diperoleh keterangan yang jelas, langsung, dan lugas mengenai karakteristik kepribadian orang tersebut dan pada gilirannya dapat meramalkan tingkah laku (Catrunada, 2014).

Ciri yang dapat dikenali dari kepribadian introvert yaitu kecenderungan mudah tersinggung, perasaan mudah merasa disakiti, mudah gugup, perasaan rendah diri, mudah melamun, gangguan tidur, intlegensi relatif tinggi, perbendaharaan kata baik, konsisten, teliti tapi lambat, kaku dalam bersikap, kurang suka lelucon mengenai seks (Catrunada, 2014). Adapun ciri kepribadan ekstovert meliputi intelegensi relatif rendah, perbendaharaan kata kurang, inkonsistensi pada pendirian, cepat mengambil keputusan tapi kurang teliti, felksibel, humoris tetang seks. (Kuntjojo, 2009).

Dalam bukunya yang berjudul "Berbicara Sebagai Suatu Keterampilan Berbahasa" (Tarigan, 1983:15) mengemukakan bahwa keterampilan berbicara adalah kemampuan mengucapkan bunyi-bunyi artikulasi atau kata-kata untuk mengekspresikan, mengatakan serta menyatakan pikiran, gagasan, dan perasaan. Pendengar menerima informasi melalui rangkaian nada, tekanan, dan penempatan persendian. Jika komunikasi berlangsung secara tatap muka ditambah lagi dengan gerak tangan dan air muka (mimik) pembicara. Masih menurut Tarigan (2008:3) dalam buku Berbicara menjelaskan bahwa berbicara adalah suatu keterampilan 
berbahasa yang berkembang pada kehidupan anak yang hanya didahului oleh keterampilan menyimak, dan pada masa tersebutlah kemampuan berbicara atau berujar dipelajari. Djago Tarigan (1990 : 149) menyatakan bahwa berbicara adalah keterampilan menyampaikan pesan melalui bahasa lisan. Arsjad dan Mukti U. S (1993:23) mengemukakan bahwa kemampuan berbicara adalah kemampuan mengucapkan kalimat-kalimat untuk mengekspresikan, menyatakan, menyampaikan pikiran, gagasan, dan perasaan.

Adapun pendapat lain menyatakan bahwa Speaking is an interactive process of constructing meaning that involves producing and receiving and processing information (Brown, 1994; Burns \& Joyce, 1997). Its form and meaning are dependent on the context in which it occurs, including the participants themselves, their collective experiences, the physical environment, and the purposes for speaking. It is often spontaneous, open-ended, and evolving. Language functions (or patterns) that tend to recur in certain discourse situations (e.g., declining an invitation or requesting time off from work), can be identified and charted (Burns \& Joyce, 1997).

Pendapat di atas berarti bahwa berbicara merupakan proses interaktif untuk membangun makna yang meliputi produksi informasi dan penerimaan informasi (Brown, 1994; Burns \& Joyce, 1997). Bentuk dan maknanya bergantung pada konteks pembicaraan, pesan/ maksut yang ingin diungkapkan pembicara, pengalaman, lingkungan, dan tujuan berbicara. Berbicara sering dilakukan secara spontan, terbuka, dan berkembang. Fungsi bahasa yang cenderung terulang dalam situasi wacana tertentu (misal menolak undangan atau meminta cuti dari pekerjaan), dapat diidentifikasi dan dipetakan (Burns \& Joyce, 1997). Berbicara merupakan kunci komunikasi. Dengan mempertimbangkan tugas berbicara apa yang dapat dipraktekkan di kelas, dan kebutuhan peserta didik, pendidik dapat membantu peserta didik meningkatkan kemampuan berbicara mereka.

\section{Hubungan Kepribadian Introvert Dan Ekstrovert Dengan Speaking Skill}

Kepribadaian merupakan sifat yang hakiki yang khas yang dimiliki oleh individu, (Tarmidzi, 2012) dan ciri khas tersebut yang dapat membedakan antara 
individu yang satu dengan yang lain (Edwina Renaganis Rosida \& Tri Puji Astuti, 2015). Kepribadaian introvert memiliki kecenderungan untuk pasif dan ekstrovert cenderung lebih aktif terutama pada lingkungan eksternal (Anya Cahyaning, 2015), meskipun dalam praktiknya tidak ada tipe kepribadian yang menggambarkan introvert atau esktrovert murni (Zubaidah, 2017). Kepribadian ekstrovert merupakan tipe kepribadian yang orientasi terutama tertuju pada dunia luar dan tindakan banyak dipengaruhi oleh lingkungan, sedangkan introvert memilki kecenderungan bersifat diam, tidak bergaul dengan orang lain (Azizah, 2016). Perbedaan kedua kepribadain tersebut dapat berpengaruh pada kemampuan komunikasi individu dengan lingkungan (Zubaidah, 2017). Kepribadian introvert mememiliki kecenderungan berkomunikasi lebih baik dari pada ekstrovert, demikian juga dalam berkomunikasi menggunakan Bahasa Inggris. (Samandi, 2014).

Untuk mengukur tipe kepribadian menggunakan test kepribadian. Hasil test dapat negatif atau positif (Tarmidzi, 2012). Sedangkan faktor kebahasaan yang dikutip dalam buku Language Test at School karya John Oller yang menggunakan Rubric of Speaking Assessment menjadi pedoman dalam menilai keterampilan berbicara seseorang. Adapun aspek aspek yang dinilai dalam tes berbicara menggunakan Bahasa Inggris meliputi: (1). accent (logat), (2). grammar (tata bahasa), (3). vocabulary (kosa kata), (4). fluency (kefasihan), dan (5). comprehension (pemahaman).

\section{Metode}

Penelitian ini dilaksanakan di AKES Rustida Prodi D III Keperawatan Krikilan Glenmore Banyuwangi. Waktu penelitian pada bulan Oktober sampai Desember 2017. Jenis penelitian ini adalah deskriptif kuantitatif non eksperimental. Penelitian ini menggunakan metode deskriptif cross sectional dengan tujuan untuk mengetahui hubungan tipe kepribadian introvert dan ekstrovert dengan speaking skill pada mahasiswa semester I AKES Rustida Prodi DIII Keperawatan Tahun Ajaran 2017/2018. Menurut Sugiono (2009) populasi merupakan "wilayah generalisasi yang terdiri atas objek atau subjek yang 
mempunyai kuantitas dan karakteristik tertentu yang ditetapkan oleh peneliti untuk dipelajari dan kemudian ditarik kesimpulannya". Populasi penelitian ini adalah mahasiswa semester I Prodi DIII Keperawatan. Sampel penelitian sebanyak 38 subyek. Tehnik pengambilan sampel secara random sampling yaitu seluruh subyek berkesempatan menjadi sampel penelitian. Sugiyono (2013) menyatakan variabel adalah "pengelompokkan yang logis dari dua atribut atau lebih". Variabel penelitian ini dioperasionalisasikan sebagai Variabel Bebas (X1) yakni tipe kepribadian introvert dan (X2) tipe kepribadian ekstrovert. Variabel Terikat (Y) adalah speaking skill.

Data tipe kepribadian diperoleh dengan menggunakan kuesioner. Penentuan skor untuk keribadian intovert skor kurang dari 68,93 dan ekstrovert lebih dari 68,93 . Sedangkan untuk skor speaking skill data didapatkan melalui tes kemampuan berbicara atau speaking terhadap 5 aspek kemampuan dasar, kemudian nilai yang didapatkan dikonversikan dan diinterpretasikan berdasar skala kemampuan berbicara dengan rentang 0-4.

Data yang diperoleh kemudian dianalisis menggunakan tehnik statistik. Dengan tujuan memperoleh gambaran selama penelitian. Teknik analisis kolmogrov smirnov test digunakan untuk mengetahui hubungan tipe kepribadian intovert dan ekstrovet dengan speaking skill. Kemudian untuk menunjukkan apakah variabel bebas mempunyai pengaruh terhadap variabel terikat dan seberapa besar pengaruh kedua variabel bebas terhadap vaiabel terikat yang dianalisis dengan bantuan SPSS 22.00 (Riwidikdo, 2009). Analisis kepribadan introvert dan ekstrovert dalam penelitian ini menggunakan skala Personal Style Inventory (PIS) meliputi aspek mengenali afektif dan kognitif.

Sedangkan untuk mengetahui nilai speaking mahasiswa dilakukan penilaian speaking, dan nilai dianalisis menggunakan Rubric of Speaking Assessment yang dikutip dari buku yang ditulis oleh John Oller yang berjudul Language Test at School terhadap 5 aspek dasar penilaian meliputi accent (logat), grammar (tata bahasa), vocabulary (kosa kata), fluency (kefasihan) dan comprehension (pemahaman). 
Sampel penelitian ini adalah mahasiswa semester I Prodi D III Keperawatan Rustida sebanyak 38 subyek. Pada tabel berikut disajikan data karakteristik subyek berdasarkan jenis kelamin.

Tabel 1 : Distribusi frekuensi responden mahasiswa semester I Prodi D III Keperawatan Tahun Ajaran 2017/2018

\begin{tabular}{ccc}
\hline Jenis kelamin & Frekuensi & Prosentase \\
Laki-laki & 11 & $29 \%$ \\
Perempuan & 27 & $71 \%$ \\
Jumlah & 38 & 100 \\
\hline
\end{tabular}

Berdasarkan tabel di atas dapat disimpulkan bahwa distribusi frekuensi responden mahasiswa semester I Prodi D III Keperawatan Tahun Ajaran 2017/2018 laki laki sebanyak 16 (32\%), sedangkan mahasiswa perempuan sebanyak 34 (68\%).

Tabel 2 : Analisis frekuensi kepribadian introvert dan extrovert mahasiswa semester I Prodi D III Keperawatan Tahun Akademik 2017/2018

\begin{tabular}{ccc}
\hline Kepribadaian & Frekuensi & Prosentase \\
Introvert & 18 & 47 \\
Extrovert & 20 & 53 \\
Jumlah & 38 & $100 \%$ \\
\hline
\end{tabular}

Berdasarkan tabel di atas dapat disimpulkan bahwa distribusi frekuensi tipe kepribadian mahasiswa semester I Prodi D III Keperawatan Tahun Ajaran 2017/2018 sebanyak 18 (47\%) untuk kategori introvert, sedangkan kepribadian extrovert sebanyak 20 (53\%).

\begin{tabular}{|c|c|c|c|c|c|c|}
\hline \multirow{2}{*}{$\begin{array}{l}\text { Tabel } 3 \\
\text { Kepribadian }\end{array}$} & \multicolumn{6}{|c|}{$\begin{array}{l}\text { Analisis frekuensi kepribadaian introvert dan extrovert dengan } \\
\text { speaking skill mahasiswa semester I Prodi D III Keperawatan Tahun } \\
\text { Akademik 2017/2018 }\end{array}$} \\
\hline & \multicolumn{5}{|c|}{ Speaking skill level } & Jumlah \\
\hline \multirow[b]{2}{*}{ Ekstrovert } & 0 & 1 & 2 & 3 & 4 & \\
\hline & $\begin{array}{c}2 \\
(10 \%)\end{array}$ & $\begin{array}{c}7 \\
(35 \%)\end{array}$ & $10(50 \%)$ & $\begin{array}{c}1 \\
(5 \%)\end{array}$ & $\begin{array}{c}0 \\
(0 \%)\end{array}$ & $20(100 \%)$ \\
\hline \multicolumn{7}{|c|}{ Speaking skill level } \\
\hline \multirow[t]{2}{*}{ Introvert } & 0 & 1 & 2 & 3 & 4 & \\
\hline & $\begin{array}{c}1 \\
(6 \%)\end{array}$ & $\begin{array}{c}8 \\
(44 \%)\end{array}$ & $\begin{array}{c}9 \\
(50 \%)\end{array}$ & $\begin{array}{c}0 \\
(0 \%)\end{array}$ & $\begin{array}{c}0 \\
(0 \%)\end{array}$ & $18(100 \%)$ \\
\hline
\end{tabular}

Kesimpulan yang didapat berdasar tabel di atas bahwa distribusi frekuensi tipe kepribadian dengan speaking skill level pada responden mahasiswa semester I 
Prodi DIII Keperawatan Tahun Ajaran 2017/2018, yaitu tipe kepribadian ekstrovert sebegaian besar berada pada level 2 sebanyak 10 (50\%) responden, sedangkan mahasiswa dengan tipe kepribadaian introvert dengan speaking level sebagian besar level 2 sebanyak $9(50 \%)$.

Tabel 4

: Uji t test perbedaan antara tipe kepribadian ekstrovert dan introvert dengan dengan speaking skill mahasiswa semester I Prodi D III Keperawatan Tahun Akademik 2017/2018

\begin{tabular}{cccccc}
\hline Tipe Kepribadian & $\mathbf{n}$ & $\mathbf{p ~ V a l u e}$ & Mean & SD & t \\
Extrovert & 20 & & 1.5000 & 0.76089 & -0.246 \\
Introvert & 18 & 0.807 & 1.4444 & 0.61570 &
\end{tabular}

Hasil uji independent sample t-test di atas menunjukkan nilai signifikansi $\mathrm{p}=0,807(\mathrm{p}>0,05)$ dengan nilai $\mathrm{t}-0.246$ sehingga dapat disimpulkan tidak terdapat perbedaan yang bermakna antara tipe kepribadian ekstrovert dan introvert dengan speaking skill pada mahasiswa semester I Prodi DIII Keperawatan Tahun Ajaran 2017/2018.

\section{Hasil dan Pembahasan}

Penelitian ini dilakukan untuk mengetahui ada atau tidaknya perbedaan tipe kepribadian introvert dan ekstrovert dengan speaking skill. Tipe kepribadian ekstrovert maupun introvert merupakan suatu rentang dalam sebuah skala pengukuran kepribadian, sehingga kebanyakan orang akan berada ditengah-tengah kedua tipe kepribadian tersebut sehingga dapat dikatakan orang tersebut bertipe kepribadian ambivert, dan hanya sedikit dari orang sekitar yang benar- benar memiliki tipe kepribadian introvert maupun ekstrovert (Azizah, 2016).

Jumlah total subjek penelitian sebanyak 38 orang, yang diperoleh dari hasil klasifikasi berdasarkan tipe kepribadian ekstrovert (53\%) dan introvert 18 (47\%). Mayoritas subjek penelitian berjenis kelamin perempuan sebanyak 27 dan laki-laki sebanyak 11. Sebagian besar subjek penelitian ini memiliki kepribadian ekstrovert dengan speaking skill berada pada level 2 yaitu mampu berbicara menggunakan kosakata yang tepat, menguasai kosa kata yang baik dan mampu berkomunikasi dalam konteks formal dan non formal sebanyak 10 (53\%) 
demikian juga dengan tipe kepribadian introvert sebagaian besar berada pada level 2 sebanyak 9 subyek (47\%).

Hasil penelitian ini menunjukkan nilai $p 0.807>0.05$ yang artinya tidak ada perbedaan secara bermakna antara tipe kepribadian ekstrovert dan introvert terhadap speaking skill hasil ini berbeda dengan peneliti terdahulu yang menemukan fakta bahwa kepribadian introvert memiliki speaking skill yang kurang baik (Zubaidah, 2017). Speaking skills setiap orang tidak sama terlebih dalam komunikasi dengan Bahasa Inggris, hal ini dapat dipengaruhi oleh faktor internal dan eksternal, berbagai studi menyatakan bahwa seseorang dilahirkan dengan kepribadian yang berbeda-beda yang dapat mempengaruhi bagaimana cara mereka berkomunikasi dengan dunia sekelilingnya (Zubaidah, 2017). Tipe kepribadian introvert memilki ciri pemalu, sulit menyesuikan diri dengan lingkungan (Tarmidzi, 2012) dan tipe kepribadian ini dapat berpengaruh pada model kelancaran dalam berkomunikasi dibandingkan dengan kepribdian ekstrovert (Fitri, 2014). Kepribadian introvert cenderung kurang bergaul dan sukar berhubungan dengan orang lain. Tipe kepribadian berhubungan dengan kelancaran dalam berkomunikasi atau berbahasa.

Tidak ada kepribadian murni, setiap orang pasti memiliki dua kepribadian yang mengandung variasi kompleks yang mana juga dapat mempengaruhi kelancaran komunikasi verbalnya. Kalancaran komunikasi merupakan sarana menyampaian pikiran, perasaaan dan maksut lainnya (Zubaidah, 2017). Hasil penelitian ini menyatakan tidak ada perbedaan antara kepribadian introvert dan eksrovert dengan speaking skill. Riswanti (2010) mengatakan bahwa speaking skill seseorang tidak hanya dipengaruhi oleh tipe kepribadian namun juga dipengaruhi oleh perpaduan antara herediter dan faktor lingkungan. Sedangkan faktor lain yang juga berpengaruh pada speaking skill yaitu faktor lingkungan sekitar tempat tinggal mahasiswa (Zubaidah, 2017).

Permasalahan kelancaran dalam berbahasa inggris banyak dialami oleh para mahasiswa terutama perguruan tinggi swasta. Sebagaian besar penyebab dari masalah tersebut disebabkan 1) motivasi belajar 2) peran dosen dalam pembelajaran 3) sarana dan prasarana 4) materi pembelajaran 5) lingkungan 
belajar. Pada level perguruan tinggi speaking skill harus melibatkan dosen dan mahasiswa (Hermayawati, 2010). Dalam proses belajar ketrampilan berbahasa inggris (speaking skill) langkah-langkah untuk membuat mahasiswa lebih aktif harus dirumuskan metode pembelajaran yang tepat, lebih menarik, menghindari model pembelajaran yang terlalu tegang dan harus membiasakan diri setiap hari (Sutiyoso, 2010). Dalam pembelajaran speaking mahasiswa dituntut untuk berkomunikasi secara individu atau kelompok dan dapat memahami maksud pembicaaran dengan baik, cara bicara ini menunjukkan kepribadian seseorang, kadang orang dengan kepribadain introvert cenderung lebih tenang dalam berbicara dan kadang orang dengan kepribadian ekstrovert lebih tenang dalam menyampaikan pendapat tetapi speaking skillnya kurang Lancer (Rahman, 2013).

\section{Kesimpulan dan Saran}

\section{Kesimpulan}

1. Dari total sampel yang ditentukan jumlah responden yang berkepribadian introvert sebanyak 18 responden.

2. Dari total sampel yang ditentukan jumlah responden yang berkepribadian ekstrovert sebanyak 20 responden.

3. Tidak terdapat perbedaan yang signifikan antara kepribadian introvert dan ekstrovert terhadap speaking skill mahasiswa semester I AKES RUSTIDA Prodi DIII Keperawatan TA 2017/2018.

\section{Saran}

1. Bagi para dosen/tenaga pengajar sebaiknya mencari cara yang lebih inovatif dan kreatif dalam menyampaikan proses pembelajaran guna merangsang pola pikir mahasiswa agar lebih menguasai setiap materi yang telah diajarkan.

2. Pengembangan bahan ajar seperti modul akan dapat membantu belajar mahasiswa. 
3. Dukungan positif perlu dilakukan oleh pengajar demi terciptanya proses belajar yang baik dan lebih efektif dalam membantu mahasiswa mencapai prestasi belajar.

4. Bagi mahasiswa sebaiknya lebih serius dalam menyelesikan tugas-tugas dari setiap mata ajar.

5. Dengan tugas pemahaman dan penguasaan terhadap materi mata ajar akan lebih mendalam.

\section{DAFTAR PUSTAKA}

Agus Suganda, Arif Hidayat, Indri Widayastuti, E. R. (2010). Upaya meningkatkan kemampuan bicara siswa dalam bahasa inggris melalui permainan sanke and ladder di kelas VII A SMP negeri cimahi. Bandung: UPI.

Aliyah, P. (2006). Hubungan tipe kepribadian ekxtrovert dan introvert dengan perilaku asertif pada siswa-siswi pesantren $X$ di bogor. Bogor: Universitas Bina Nusantara.

Anya Cahyaning, R. C. (2015). Perbedaan communication privacy management di media sosial twitter pada remaja dengan tipe kepribadian extrovert dan introvert. Jurnal Psikologi Pendidikan dan Perkembangan, 4(1), 65-70.

Arsjad, Maidar G. dan Mukti, U.S. (1993). Pembinaan kemampuan berbicara bahasa indonesia. Jakarta: Erlangga.

Ayu, D., Wiryadi, A., Ayu, P., \& Dharmayanti, P. (2016). Pengaruh anxiety dalam speaking activities. Jurnal Bakati Saraswati, 05(02), 2088-2149.

Azizah, Y. N. (2016). Perbedaan antara tipe kepribadian ekstrovert dan intovert dengan tingkat stres pada mahasiswa fakultas hukum universitas muhammadiyah surakarta. Surakarta: Universitas Muhammadiyah Surakarta.

Brown, H.D. (1994). Teaching by principles: An interactive approach to language pedagogy. Englewood Cliffs, New Jersey: Prentice Hall Regents.

Burns, A., \& Joyce, H. (1997). Focus on speaking: National center for english language teaching and research. Sydney: Published North Ryde, N.S.W: National Centre for English Language Teaching and Research. 
Butsi, F. I. dan D. (2016). Metode pembelajaran dan kepribadian ekstrovert serta pengaruhnya terhadap prestasi belajar. Jurnal Kultura, 17(1), 5554-5562.

Catrunada, L. (2014). Perbedaan kecenderungan prokrastinasi tugas skripsi berdasarkan tipe kepribadian introvert dan ekstrovet. Salatiga: Universitas Gunadarama Salatiga.

Edwina Renaganis Rosida \& Tri Puji Astuti. (2015). Perbedaan penerimaan teman sebaya ditijua dari tipe kepribadian ekstrovert dan introvert. Jurnal Empati, 4(1), 77-81.

Fitri, I. P. \& R. A. (2014). Hubungan tipe kepribadian ekstovert dan introvert dengan tahapan komunikasi intim pada dewasa. Jakarta: Universitas Bina Nusantara Jakarta.

Hermayawati. (2010). Analisis kesulitan belajar bahasa inggris mahasiswa. Jurnal Sosio-Humaniora, 1(1), 1-14.

Kuntjojo. (2009). Psikologi Kepribadian. Kediri: Universitas Nusantara PGRI Kediri.

Oller, John W. Jr. 1979. Language test at school: A pragmatic approach. London: Longman Group Limited.

Rahman, M. A. (2013). A Study on the correlation between personality and speaking proficiency of the first semester English literatire student of FIB UB 2012. Malang: Universitas Brawijaya.

Ratih, K. (2005). Motivasi dalam usaha meningkatkan ketrampilan wicara bahasa inggris mahasiswa jurusan non bahasa inggris universitas muhammadiyah surakarta 2001/2002. Jurnal Penelitian Humaniora, 6(1), 14-27.

Riwidikdo, H. (2009). Statistik Kesehatan. Jakarta: Rohima Press.

Samandi, S. M. (2014). Analisis hubungan kepribadian Extrovert-introvert dan kemampuan berbicara siswa program study pendidikan Bahasa Inggris Universitas Halu Oleo. Manado: Universitas Halu Oleo Manado.

Sutiyoso. (2010). Peningkatan kemampuan berbahasa inggris mahasiswa seni tari semester empat melalui $\mathrm{kbm}$ berbahasa inggris pada mata kuliah kajian dan peningatan pengembangan kurikulum dengan pendekatan cooperative learning. Yogyakarta: Universitas Negeri Yogyakarta.

Tarigan, Henry Guntur. (2008). Berbicara sebagai suatu keterampilan berbahasa. Bandung: Angkasa. 
Tarigan, Djago. (1990). Teknik Pengajaran Keterampilan Berbahasa. Bandung: Angkasa

Tarigan, Henry Guntur. (1983). Berbicara sebagai suatu keterampilan berbahasa. Bandung: Angkasa.

Tarmidzi, D. S. (2012). Hubungan antara tipe kepribadian ekstrovert dan introvert dengan prestasi akademik mahasiswa fakults tehnik universitas indonesia. Jakarta: Universitas Indonesia.

Winarso, W. (2015). Perbedaan tipe kepribadian terhadap sikap belajar matematika siswa kelas 10 sma islam al-azhar 5 cirebon personality type of attitude difference learning math class 10 sma. Jurnal Saintmart, IV(1), 6780 .

Zubaidah, C. (2017). Hubungan kepribadian introvert dengan komunikasi verbal siswa kelas 11 sman satu kademangan blitar. Kediri: Universitas Nusantara PGRI. 